\title{
Survive of the Indonesia farmers in during the Covid-19 Pademic: Findings of the South Sumatra
}

\author{
Agustina Bidarti ${ }^{1}$, \\ ${ }^{1}$ Department of Agricultural Social-economic, Faculty of Agriculture, University of Sriwijaya, \\ Palembang-Prabumulih Highway, 32th miles, 30662, Indralaya, South Sumatra, Indonesia
}

\begin{abstract}
This research aims to perform an empirical analysis of rural farmer conditions in South Sumatera during the Covid-19 pandemic outbreak. To fulfill the research objectives, there are some things focused on economic and demographic features, levels and patterns of income and consumption, the magnitude of debt factors, and social conditions and the position of farmers in society. This research is a survey study with multiple regression analysis methods. The sample selection is carried out in a multilevel with a sample number of 300 farmers in South Sumatra. Based on this study, first, during the pandemic, farmers were in a difficult condition because of the low income from agricultural products that was not balanced with consumption expenditure. Farmers' income during the pandemic amounted to 104.54 USD, a decrease from the previous year amounting to 218.28 USD. Decreased by 52.16 percent before the pandemic. Second, they survive by making debt loans. Third, reduced income and large amounts of debt have caused farmers to be unable to meet their basic needs, where around 65.22 percent of total consumption is spent on non-durable goods or only to fulfill their basic needs.
\end{abstract}

\section{Introduction}

Agriculture and plantation sectors, such as rice, rubber, coffee and palm head, and other food crops dominated the livelihood of South Sumatera society [1]. There was a sharp increase in food production in South Sumatra in several sectors such as rice, corn, peanut, cassava, and sweet potato as well as various vegetables during the period from 2001-2010[11]. This condition causes South Sumatera to have predicate as one of the fifth national Food Barns Province in Indonesia.

During 2019, South Sumatera targeted as a provincial food export gateway in Indonesia by promoting a million tonnes of dry grain per year for the district of Banyuasin, Ogan Komering Ulu Timur (OKUT), Musi Rawas and other districts through cooperation and full trust in farmers, agricultural personnel, agricultural extension, and agricultural service, and

\footnotetext{
${ }^{*}$ Corresponding Author: agustinabidarti@unsri.ac.id
} 
give confidence that there will be no influence on the production of agricultural commodities in the event of price fluctuations. The production of various food commodities from each district production center in South Sumatera is distributed to urban areas as a central supply area to be further distributed again to each other rural areas that require [3].

But amid the effort to boost farming in South Sumatera, in early 2020, the world was in a wild in the outbreak of Coronavirus Diseases 2019 (COVID-19). Viral outbreak coming from Wuhan City, China [20]. The Virus is spreading throughout the world, including Indonesia. South Sumatera is one of the COVID-19 red Pandemic zone areas in Indonesia. The agricultural sector in South Sumatra that has survived the various crises and turmoil and is considered the toughest sector to help economic stability be impacted by the pandemic. During the pandemic, agricultural sector productivity in South Sumatera declined in the first quarter of 2020. The shortage of labor due to the closure of the border between regions and changes in the food supply chain pattern in South Sumatera makes the farming situation run less normal. This quarter is the culmination of food consumer demand to fulfill the needs of its life provided from farmers farming fields in South Sumatera.

Policy on the implementation of social restriction on large scale (PSBB) in the downstream sector of the food distribution center of South Sumatera, Palembang, and Prabumulih city has a wide impact on the upstream sector of food production in rural areas of South Sumatera district. Also, public appeal so that the community, including farmers to work from home (WFH), maintaining physical distance and territorial quarantine have been a partially strong influence in the pattern of food chains in South Sumatra [17, 4]. Changes in food chain patterns amid pandemic Covid-19, both upstream and downstream, because there is a decline in the price of food commodity at the farmer level, and the decline in consumption at the consumer level gives a significant influence on the life of farmers.

Farmers in South Sumatra feel the influence of input supply and quality assurance and the safety of their products. South Sumatera farmers face new conditions due to changes in the original supply patterns in traditional markets, but during the pandemic, food supply is more geared towards modern markets and online markets [2]. In addition to this, the fulfillment of South Sumatera's food market share within the export gate was subjected to obstacles in connection with the disruption of international trade routes during the Covid-19 pandemic. Consequently, farmers' food production suffered losses due to the low price of the domestic market compared to the international market price they acquired before the Covid19 pandemic.

In addition to the problems of change of supply lines and market share that caused food price decline. Farmers are also experiencing obstacles in the production facilities, including subsidizing fertilizer and seeds that also decreased and lack of technical guidance from the agricultural extension in the field because of the policy of working from home (WFH). Such production facilities led to the condition of demand for agricultural products in South Sumatra in the majority of smallholder farmers experiencing a sharp decline $[9,13,5]$. The condition of declining production and the cheap price of food commodities in South Sumatra is parallel with the findings in the field that shows the efforts of the farmers to survive in the economic waves of his household. They strive to meet the needs of family life, fulfill the agricultural capital while paying various loan credits that have been done before the Covid19 pandemic. Depressing conditions in the last three months from February to April 2020 spread almost all rural districts in the food production center in South Sumatra.

This research on the condition of farmers is important because the impact is expected to continue within a long period. The Government of Indonesia should respond and find the best solution because this condition can cause the decline of food commodity production at the farmer. The estimate of the decline in food commodities is closely related to the data of the Food and Agricultural Organization (FAO) stating that the current world food prices are still within reasonable limits, at least until March 2020. However, if the trend is seen in the 
previous year, the price of world food in nominal and real will begin to increase in October to the end of the year [6]. Along with the Covid-19 pandemic that is expected to continue until the end of this year, the Indonesian Government and also the province of South Sumatera is very important to respond immediately to the impact and possibilities that will occur in the food farming sector in South Sumatra. There must be a policy from the perspective of food supply and demand because there is a tendency to decrease the production of food commodities at the farmer level and increase the demand for food in the community household level is widespread [19]. Not until when the food demand trend increases, there will be food shortage due to the upstream sector of agriculture as producers are not able to produce well.

One factor in preventing food scarcity is crucial to ensure that the national food supply chain continues to function in the supply of food supplies [14]. Therefore, as a provider of food resources for all walks of life, the main producers of food are farmers who must be sure to continue producing during the pandemic period in a way that is considered and improved households' economy. In the early stages, the government has established a program in the form of direct cash assistance (BLT) during the pandemic of IDR 600,000 the association. But based on the findings, this assistance has not enough needs for their lives. The credit lightening Program also launched the government but has not touched the essence of the problem in the agriculture sector, because the policy of credit financing waivers is delaying the payment of credit installment for one year but interest per month must be paid even though the installment cut half. Based on the field findings, the farmers who took the credit still prefer to pay repayments even if they have applied for waivers because they do not want to be burdened with the payment of interest that remains calculated on the running time.

The miserable condition of farmers in South Sumatra during this pandemic is a lesson that can be learned. The understanding of this study should be responded to and become a view to building better conditions for farmers during the pandemic so that they can still produce food commodities not only to meet their economic needs but also to prevent the emergence of a wide food crisis. This research aims to perform an empirical analysis of rural farmer conditions in South Sumatera during the Covid-19 pandemic outbreak. This study was conducted for 4 months at the beginning of 2020, effective from February, March, April, and May 2020. To fulfill the research objectives, there are some things focused on economic and demographic features, levels and patterns of income and consumption, the magnitude of debt factors, and social conditions and the position of farmers in society.

\section{Materials and Methods}

\subsection{Study Area}

This study analyzes the impact of the Covid-19 pandemic on farmer life, especially for the level of income and debt borne by farmers in agriculture in Indonesia. Indonesian farmers are used as samples obtained from agricultural communities in the province of South Sumatra, namely Ogan Komering Ilir Timur District, Musi Rawas District, and Penukal Abab Lematang Ilir District. These three districts are mostly rural communities with the majority of households living in agriculture, just like other regions in Indonesia [12, 7]. Methodology to answer the research objectives 17 cities and regencies in South Sumatera province divided into three regions based on the value of regional productivity, namely low, medium, and high productivity areas. The average value of productivity is taken from the aggregation of the 10 main crops in South Sumatera province.

Based on the average value of 10 productivity plants from the sample counties, the East Ogan Komering Ulu (OKUT) district was chosen from the high-value productivity area as 
well as representing the southern region, Musi Rawas (MURA) district was selected from medium-valued productivity areas as well as representing the northern region, and the PALI (Penukal Abab Lematang Ilir) District was selected from low-value productivity areas as well as representing the central region. Based on the three districts, the sample follows a random sampling method, selected fifteen villages in the three districts, five villages from OKUT district, five villages from MURA district and five villages from PALI district have been selected for this research. All farmers ' houses from selected sample villages are investigated from selected districts in giving an overview of the farmer's condition during the Covid-19 pandemic. Based on this there are a total of 300 farmer households from 15 sample villages investigated. A total of 100 households from the OKUT district, 100 households from the MURA district, and 100 households from the PALI district.

As outlined from the research objectives, research studies are focused on the economic features and demographics of the sample area, the level and pattern of income and the sample household consumption, magnitude and debt determinant factors, and their social condition and position in agricultural communities in Indonesia. Based on the focus of the study, it will be summarised key findings, making some strategic suggestions, and recommendations to further research.

\subsection{Data Collection}

Data in this study was obtained from the main source of the use of structured questionnaires. This study uses a randomized multi-stage sampling technique in selecting each household community in the three selected regions. At the first stage, people in the three districts of the group were to be selected randomly from several districts in the south, central, and northern regions of South Sumatera. In the second stage, random sampling is used to select 100 farmers from each district, so that the total number of 300 farmers is based on the underlying agricultural commodity of rice, rubber, palm oil, coffee, corn, cassava, peanut, green beans, and sweet potato. Also, these farmers are the utilization of financial credit loans, both in financial institutions and non-financial institutions.

The main person in this survey is the students who are at the research site. They have emotional and regional proximity to those sample farmers. Therefore, at the final stage of the selected farmers are chosen randomly with the reference makes it easy to conduct surveys during the Covid-19 pandemic. The farmers had an emotional closeness with the main person. In addition to survey data, this research also uses the data of the Central Bureau of Statistics, and key informants such as some head of the service, head of local banking branch, and the head of the farmer group at the research site. Raw data from the Central Bureau of Statistics in the South Sumatera region in search of data for per capita income, further processed from the findings of data also obtained from farmers, local agencies, heads of local bank branches, and the leaders of farmer groups in each of these districts. Therefore, there may be some differences between statistical data and the per capita income in the survey can be aligned.

The total data of the farmer's household income per capita in this study was the previous year's data used as a comparison of farmers' revenues during the Covid-19 pandemic. Revenue during the Covid-19 pandemic, and per capita income was the sum of cash revenues, income from agriculture sources, and revenue from non- agriculture sources. The income derived from agriculture is revenue from the cultivation of the harvest of the ten agricultural commodities of farmers, such as income from the harvest of rice, rubber, palm oil, coffee, corn, cassava, soybean, peanut, green beans, and sweet potato. While cash revenue is usually the salary of civil servants, private employee salaries, or household income sourced from the amount of income of his child's salary. Non-farm income will be the side activities of farmers such as entrepreneurs, such as opening grocery stores, livestock, or other fisheries received 
by family members, such as household heads, spouses, and other active members of the economy.

Total household income per capita defines the total household income relative to their size. The total household income of farmers is taken from processed various data, such as survey data, data of the Central Bureau of Statistics, banking institutions, and rural credit institutions. The big difference in household income of some farmers comes from gaps in cash revenues, agricultural source income, and non-agricultural source income which is subsequently sought by the average. Likewise, if there is a data discrepancy for per capita household income is sought to average the fact that households have relative size revenues that are not too large between one farmer and another. However, these average descriptive statistics are not detached from the computation of bias. Therefore, to minimize the calculation of bias, also carried out data selection that may be approaching the existing truth and close to the size of the data from the Central Bureau of Statistics that exist in the research site. Besides, the data in this study was compared seriously with data derived from the socioeconomic factors, agricultural and financial institutions of particular.

\subsection{Data Analysis}

This research uses three combinations of econometric techniques to assess the impact of the Covid-19 pandemic on the living conditions of the farmers, in this case, the income and productivity of farmers in Indonesia on staple crop commodities, especially in South Sumatera. Firstly, using simple regression is referred to as regression on covariates in calculating levels and patterns of income as well as household consumption of samples. Secondly, a tendency form regresses the value of life by using a regression on a propensity score from the calculation of bias selectivity in estimating the effects of the farmers' financial use of samples in the form of magnitude calculations and the determinant of farmers' debt sampling factors. In the third stage, it is equipped with the Heckman treatment effect model to test the robustness of the results that can be from the impact of the Covid-19 pandemic in the field of major crop commodities in South Sumatera, Indonesia. The third stage begins with the consideration that the variable results, in this case, the results of the underlying commodity of farmers, agricultural income per capita, total household income, and the total household income per capita are analyzed by the calculation of linear functions.

The explanation of socioeconomic factors such as Corletto et al. in the farmer's household affected by the Covid-19 pandemic is generally regarded as capable of describing variations in the state of the field faced by peasant households during the Covid-19 pandemic. [8] The study of Bashir et al. Also analysts the size of household, education, livestock, and income in understanding the variations in food security of food households when the crisis emerged in rural Pakistan [15].

The current study uses four continuous variables consisting of total credit from various institutions, both financial institutions, and non-institutional finance and binary variables, the total number of members of the farmer's household, and the level of education in the farmer's household as a socioeconomic indicator. Multiple regression analyses in this study used linear functions.

\section{Results and Discussion}

\subsection{Socio-economic characteristics of farmers}

In this section, data on the socio-economic characteristics of farmers during the pandemic period Covid-19, which is data on the social and economic characteristics of farmers in South Sumatera. These characteristics concern gender, age, family members, education, a land area 
owned by farmers. Based on samples taken from 300 houses of farmers in South Sumatera there are a total of 1204 people with male gender with a percentage of 62.13 percent ( 748 people) and female gender with a percentage of 37.87 percent (456 people).

Based on samples there are under 20 years of age 16.45 percent (198 people), between 21 years to 40 years of 32.56 percent (392 people), between 41 to 60 years of 40.45 percent ( 487 people), 60 years and above, 10.55 percent (127 people). The size of the farmer family sample is at an average amount of 3.12. Education samples Some farmers did not finish the primary school amounted to 13.12 percent, graduated from primary school 40.37 percent graduated junior high at 15.53 percent, graduated high school at 30.32 percent, diploma there 0.50 percent, and a bachelor of 0.17 percent. It is a very interesting finding that the average land area of the farmer sample is 0.87 ha.

\subsection{Farmer's economic condition}

The economic condition discussed in this section is the presentation of survey data on the analysis of income per capita and consumption expenditure of farmer households in South Sumatera during the Covid-19 pandemic. Based on the average data of the farmer's household during the Covid-19 pandemic, it earned an income of 107.43 USD per month, comprising 87.57 percent of the agricultural sector and the remaining 12.43 percent of the nonagricultural sources as shown in table 1 . Based on the table during the quarter of the pandemic Covid-19 farmers in South Sumatera still rely on the source of income from rice farming that is at a percentage of 22.21 percent, while the source of income from rubber farming is 14.88 percent, and farming the head of the palm by 13.20 percent. In addition to planting rice, rubber, and palm oil, farmers also cultivated a corn crop of 12.28 percent, cassava 5.72 percent, soybeans 4.07 percent, peanut at 3.29 percent, green beans 2.75 percent and sweet potato by 2.76 percent. Based on income from agricultural sources acquired reality field that the farmer only gets the average income during the month-quarter pandemic Covid-19 amounting to 91.49 USD each month.

Table 1. Levels, Patterns and Distribution of Per Capita of Farmers Household Income in South Sumatra during the Covid-19 Pandemic

\begin{tabular}{|l|c|c|c|}
\hline Sources of income & Mean income & Percent & Per capita \\
\hline (a) Cash & 10.12 & 9.68 & 18.39 \\
\hline (b) Agricultural sources & \multicolumn{3}{|l|}{} \\
\hline (i) Rice & 23.21 & 22.21 & 39.50 \\
\hline (ii) Rubber & 15.55 & 14.88 & 33.34 \\
\hline (iii) Palm oil & 13.80 & 13.20 & 33.40 \\
\hline (iv) Coffee & 12.83 & 12.28 & 28.66 \\
\hline (v) Corn & 6.70 & 6.41 & 13.93 \\
\hline (vi) Cassava & 5.98 & 5.72 & 13.75 \\
\hline (vii) Soybean & 4.25 & 4.07 & 8.89 \\
\hline (viii) Peanuts & 3.44 & 3.29 & 8.56 \\
\hline (ix) Green beans & 2.88 & 2.75 & 7.15 \\
\hline (x) Sweet potato & 2.85 & 2.76 & 7.14 \\
\hline Sub-total & 91.49 & - & 222.98 \\
\hline (c) Non-agricultural sources & 2.89 & 2.75 & 6.85 \\
\hline Total & 107.43 & - & 248.22 \\
\hline
\end{tabular}

Sources: Analysis of Field Survey Data, 2020 
Farmer's income from non-agricultural sources is calculated from some farmers' side businesses such as grocery stores, poultry, animal cattle, and other side activities quarterly during the Covid-19 pandemic average of only 2.75 percent or 2.89 USD. While the cash can be saved every month which is a deposit, both from retirement money and from salary resulting from the work of his children and others only amounted to 9.28 percent or 10.12 USD. Farmers' income in South Sumatera during the Covid-19 pandemic, furthermore, compared with the quarterly income during the Covid-19 pandemic during the same month in the previous year, in 2019. The per capita income of the communities in South Sumatera is still too far and unbalanced. The average income of farmers ' households per month during the early quarter of 2019 was 248.22 USD. The income of 2019 was obtained from agricultural sector revenues of 222.98 USD and the remainder of the cash revenue of 18.39 USD plus from the non-agricultural sector of 6.85 USD.

Besides revenues, to see the socio-economic condition of farmers in South Sumatera during the Covid-19 pandemic also analyzed consumption expenditure. The consumption expenditure is calculated during the month-quarter when the Covid-19 pandemic occurs in February, March, April, and May 2020. Based on the analysis, it was seen that during the Covid-19 pandemic, farmers in South Sumatra had an average household consumption rate of 134.02 USD as shown in table 2.

Overall consumption expenditure of a household farmer in South Sumatera during the Covid-19 pandemic has spent most of their income on the consumption of goods that were not durable at 65.22 percent. Subsequent consumption was followed by consumption expenditure for services amounting to 14.66 percent, for social-religious ceremonies of 10.58 percent and for goods that were durable by 9.54 percent. In terms of expenditure of consumption of goods that are not durable, namely food grains, such as rice, corn, and beans accounted for the largest proportion of total consumption expenditure with 22.58 percent, wages for farmers by 14.72 percent, side dishes such as fish, chicken, and vegetables by 12.36 percent, followed by the consumption of water drink of 8.44 percent and milk and other dairy products of 7.12 percent. Compared with consumption expenditure per month and per capita of the average farmer's household in South Sumatera in the previous month, the year 2019 of average agricultural work is 168.69 USD. Highest and least per capita expenditures are for non-durables and durables goods of 112.82 USD and 16.80 USD respectively.

Table . Levels, Patterns, and Per Capita Distribution of Farmers Consumption Expenditures in South Sumatra during the Covid-19 Pandemic

\begin{tabular}{|l|c|c|c|}
\hline Type of consumption & Expenditure & Percent & Per capita \\
\hline Non-durables goods & 87.42 & 65.22 & 112.82 \\
\hline Durables goods & 12.78 & 9.54 & 16.80 \\
\hline Services & 19.64 & 14.66 & 21.92 \\
\hline Social-religious Ceremonies & 14.18 & 10.58 & 17.15 \\
\hline Total & 134.02 & 100 & 168.69 \\
\hline
\end{tabular}

Sources: Analysis of Field Survey Data, 2020

Based on table 2 above, the trend on average consumption, in the year when the Covid19 pandemic and the previous year's data per capita there was a reduced rate of 34.62 USD. Based on this it appears that during the time of the Covid-19 pandemic, farmers in South Sumatra have tried to control the expenditure, along with declining income levels. Their households survive by lending from various money lending institutions around them.

Debt analysis conducted on the farmer's household during the pandemic. The total debt of this farmer constitutes the amount payable by the sample farmer including paying interest from the underlying debt. Based on data analysis there is a reality that more than three quarters or as much as 76.33 percent of farmer households are indebted. The average number 
of debts per household sample is 46.70 USD, while the average amount of debt per household owed is 49.04 USD. The state of farmer household debt in South Sumatra during the Covid19, as presented in table 3 below:

Table 3. Distribution of indebted of farmers households in South Sumatra during the Covid-19 Pandemic

\begin{tabular}{|l|c|}
\hline \multicolumn{1}{|c|}{ Description } & South Sumatra \\
\hline Sampled households (number) & 300 \\
\hline Indebted households (number) & 229 \\
\hline Indebted households a percentage of sampled households & 76.33 \\
\hline Amount of debt (Rs.) per sampled household & 46.70 \\
\hline per indebted household & 49.04 \\
\hline
\end{tabular}

Sources: Analysis of Field Survey Data, 2020

According to table 3, analysis reveals that non-institutional institutions play a larger role in lending to farmer households in South Sumatra when the Covid-19 takes place. According to table 4, farmers in South Sumatra during the pandemic were borrowing 50.81 percent of non-institutional agents and the remaining only 49.19 percent of institutional agents. Among the non-institutional institutions, the farmers make the most loans to traders. Besides traders, they also borrow money to money lenders for 17.63 percent and relatives or friends by 6.92 percent. Greater lending patterns to traders and money lenders than relatives and friends, because at the same time relatives and friends also have financial difficulties.

Furthermore, lending at official financial institutions amounting to 49.19 percent, lending to commercial bank institutions by 30.86 percent and cooperative institutions and other rural community credits by 18.33 percent. During the pandemic, farmer households in South Sumatra were easier to obtain loans from non-institutional institutions than the official financial institutions. Most of the debt to official financial institutions was carried out in the period before the pandemic. At the time of the pandemic, a loan submission to an official financial institution such as a bank formalized a long time consuming and complicated procedures. Also, generally, official financial institutions are more stringent for lending to them due to a lack of security guarantees during the pandemic.

Table 4. Pattern of debt according to the source of farmers credit in South Sumatra during the Covid19 Pandemic

\begin{tabular}{|l|c|}
\hline \multicolumn{1}{|c|}{ Sources of credit } & Amount of loan \\
\hline A. Non-financial institutional resources & \\
\hline 1. Moneylenders & 17.63 \\
\hline 2. Traders & 26.26 \\
\hline 3. Relatives and friends & 6.92 \\
\hline Sub-total & 50.81 \\
\hline B. Financial institutional resources & 18.33 \\
\hline 1. Co-operative credit societies/ banks & 30.86 \\
\hline 2. Commercial banks & 49.19 \\
\hline Sub-total & 100 \\
\hline Total (A+B) & \\
\hline
\end{tabular}

Sources: Analysis of Field Survey Data, 2020

According to table 4, analysis is conducted on the purpose of loans taken by farmers in South Sumatra during the duration of Covid-19. Therefore, the purpose of lending is presented in table 5. Based on table 5, it is revealed that the borrowing of money made by 
farmers is spent 32.47 percent to fulfill the needs of household consumption. Based on the total distribution of the loan, it can be said that the farmers focus their loan credits to fulfill their daily life.

Table 5. Pattern of farmers loans in South Sumatra during the Covid-19 Pandemic: Purpose-wise (In Percentage)

\begin{tabular}{|l|c|}
\hline \multicolumn{1}{|c|}{ Proportionate Share } & Purpose of Loan \\
\hline 1. Self-occupation & 6.65 \\
\hline 2. Education & 16.60 \\
\hline 3. Livestock & 15.48 \\
\hline 4. Marriage and other social-religious ceremonies & 1.52 \\
\hline 5. House construction & 5.85 \\
\hline 6. Health care & 16.32 \\
\hline 7. Domestic consumption & 32.47 \\
\hline 8. Miscellaneous & 5.11 \\
\hline Total & 100 \\
\hline
\end{tabular}

Sources: Analysis of Field Survey Data, 2020

Furthermore, analysis of various interest rates of farmer loans in South Sumatra during the Covid-19 was shown in table 6. Based on table 6 interest rates per year are more performed by financial institutions such as banks. Also, bank loans that there is interest occur on loans with traders and money lenders as well as cooperatives. Interest-less loans are only available on borrowing money made with relatives and friends. The highest interest loans are found in financial institutions, as many as 20.18 percents of the sample farmers borrow money at banks within the credit period of over 40 years. The loan interest in the commercial bank ranges from 8 to 16 percent.

Table 6. Farmers debt according to the rate of interest from different sources in South Sumatra during the Covid-19 Pandemic

\begin{tabular}{|c|c|c|c|c|c|c|c|}
\hline \multirow[b]{2}{*}{ Source of credit } & \multicolumn{7}{|c|}{ Rate of Interest } \\
\hline & $\begin{array}{c}\text { Zero Rate } \\
\text { of } \\
\text { Interest }\end{array}$ & $8-16$ & $16-24$ & $24-36$ & $36-40$ & $\begin{array}{l}40 \text { and } \\
\text { Above }\end{array}$ & Total \\
\hline \multicolumn{8}{|c|}{ A. Non-financial institutional resources } \\
\hline 1. Moneylenders & 0.00 & 0.00 & 0.00 & 8.66 & 8.97 & 0.00 & 17.63 \\
\hline 2. Traders & 0.00 & 7.78 & 12.46 & 6.02 & 0.00 & 0.00 & 26.26 \\
\hline 3. Relatives and friends & 4.54 & 0.00 & 0.00 & 0.00 & 0.00 & 0.00 & 6.92 \\
\hline Sub-total & 4.54 & 7.78 & 12.46 & 14.68 & 8.97 & 0.00 & 50.81 \\
\hline \multicolumn{8}{|c|}{ B. Financial Institutional resources } \\
\hline $\begin{array}{l}\text { 1. Co-operative/credit } \\
\text { societies }\end{array}$ & 0.00 & 7.79 & 4.85 & 5.69 & 0.00 & 0.00 & 18.33 \\
\hline 2. Commercial banks & 0.00 & 0.00 & 0.44 & 1.82 & 8.42 & 20.18 & 30.86 \\
\hline Sub-total & 0.00 & 7.79 & 5.29 & 7.51 & 8.42 & 20.18 & 49.19 \\
\hline Total $(\mathrm{A}+\mathrm{B})$ & 4.54 & 17.95 & 17.75 & 22.19 & 17.39 & 20.18 & 100 \\
\hline
\end{tabular}

Sources: Analysis of Field Survey Data, 2020

\subsection{Discussion}

The discussion was conducted with an analysis of several factors affecting farmers doing loans and debts. This some factors causing farmers to make the loan debt is the size of the family, credit ratio, income from household members and family education level. The in the 
form of a data series of the regression function multiple determinations. The results of the analysis are presented in table 7 below:

Table 7. Factors determining Indebtedness among farmers households in South Sumatra during the

Covid-19 Pandemic: Results of Multiple Regression Analysis

\begin{tabular}{|l|c|}
\hline \multicolumn{2}{|c|}{ Factors } \\
\hline Family size & 0.540 \\
& $(0.588)$ \\
\hline The ratio of credit from non-institutional to that from the institutional sources & 1.246 \\
& $(0.322)$ \\
\hline Income from subsidiary occupations & -2.674 \\
& $(0.248)$ \\
\hline The educational level of the decision-maker in the family & -0.784 \\
& $(0.288)$ \\
\hline $\mathrm{R}^{2}$ & 0.66 \\
\hline
\end{tabular}

Sources: Analysis of Field Survey Data, 2020

Note: Figures in parentheses indicate std. Errors

Based on table 7 above, the borrowing of money made by farmers during the pandemic, shows that credit ratios from non-institutional sources with those from institutional sources, income from household members income, and family head education levels are the main determinations of the debt or borrowing of the money. Based analyses, factors of influence with a negative sign of regression coefficient are precisely in the revenue factor of subsidiary occupations and the number of farmer family sizes of samples. Overall, all the explanatory variables can be said to be able to explain that there are 66 percent or 0.66 percent, meaning that almost all of these variables have a determination of the amount of farmer debt in South Sumatra during the Covid-19 period with a sign of negative relations in the economic factors that are the number of family and income from a family business.

Analysis results, the presentation of reality, the economy of farmers in during pandemic experienced a sharp decline in the field of family income that is no longer balanced by spending on their household consumption. The decline is in line with questioner analysis, the decline in revenues during pandemic, farmers' agricultural efforts have also regressed. Some of the results of their agricultural products have decreased prices due to changes in supply chain patterns. Farmers said that, such as the rice products, the demand for the market to be low. Due, the community consumption pattern widely during pandemics that prefer the form of online markets, than in traditional markets. Though the largest market share of rice farmers is in the traditional market. There is social in space with silence in the home and keep the social-psychic distance during the Covid-19 pandemic causing the online market to become crowded compared to traditional markets, including in rural South Sumatra. The decline in farmer income was also triggered by lower rubber prices, oil palm, and the coffee due to change in international market supply chain patterns during pandemic in South Sumatra. While the three agricultural commodities rely heavily on international market share.

Farmers also find it difficult to find labor, because of the social restriction. Rubber plants, palm oil, and coffee are very dependent on the help of the peasant laborers who accompany them to get greater results. This situation causes the farmer's income to decrease. Revenues from in non-agricultural, is also very minimal because there are difficulties due to supply of goods from the city center experienced obstacles due to social restrictions in the distribution cities, such as Palembang and Prabumulih city. During the Covid-19 pandemic, the mentoring of agricultural extension from BP3K and the agriculture agency became a step because the work from home caused employees not to be dropped to the farmers. As a result, 
the farmers never got advice and guidance, both about the cultivation and marketing of agricultural products.

Based on the study of Elaich, on the situation of farming abnormal examples in Moroccan need to have other institutional modifications that change the strength of the group and the institution replaces individual initiatives in managing agricultural resources in the emergency period.[2] The same study by Danso-Abbeam et al. said that the extension program becomes important for the dissemination of agricultural technology information to support knowledge, technical skills, managerial skills on agricultural development by rural farmers.[10] Therefore, learning from the study, in Indonesia the individual strength of farmers must remain supported by the service institutions in the region and the central government in getting further guidance. This guidance is required by the farmer, both at the time and after the Covid-19 pandemic.

The declining income conditions, both from agricultural and non-agricultural sources and cash, cause farmers to be in a miserable condition, to pursue the way to survive the money lending or indebtedness, both on official and non-official financial institutions, such as traders, money lenders, or through relatives and friends. Interestingly, for the survival of farmers to borrow money to a source of both non-formal financial institutions and official financial institutions. However, the borrowing of money is more aimed at consumptive efforts that are fulfilling their daily needs, not on productive businesses. As a result, farmers stuck on debt during the Covid-19 period in South Sumatra. In long term conditions, the debt will continue to choke them. Therefore, the condition of farmers who survive in a bad way must be done and further government policy is taken, so that they get out of debt.

Also, direct government policy to the problem of overcoming farmers' debts with regulations related to farmers. Based on the study of Nasrin et al. (2018), subsidized fertilizer that has a significant impact on increasing agricultural efficiency is marginal, so during and after the Covid-19 pandemic, it needs a policy of declining prices of several means of production, such as fertilizer, seeds, and pesticides with cheap prices and smooth distribution[16]. Besides, the problem of subsidizing agricultural needs, to raise farmers' income. A government needs to take strategy policy in addressing the increasing stock of domestic food demand and to move the import increase overseas during and after the Covid19.

\section{Conclusions and Recommendations}

This study is an initial analysis of the pathetic condition of farmers in South Sumatra during the early period of the Covid-19 first quarter, February, March, April, May 2020. During this time it was indicated that farmers were in a tough and precarious period due to the low income of its agricultural products. Their declining income also on the other hand is faced by its imbalance with daily consumption expenditure. So the pattern of survival is like a large stake from the pole, causing them to perform various loans and debts to various parties. The condition of farmers in South Sumatra is in a precarious situation. Considering they will also try to farm and must have a farm capital for the next and further efforts, but they already do borrower's money and interest debts that they should pay each month. The government has taken several policies, such as cash assistance of 40.86 USD quarterly. Bank credit installment payment alerts with payment installments. But this policy is still partial because it is still at the level of assisting finance to fulfill daily needs. This means that the direct solution that can overcome the obstacles to the agricultural capital that the farmers can suffer is not seen at all. During the Covid-19 pandemic, farmers still rely on the remainder of the needs of the days for their land business capital which is still very lacking.

Farmer's income during the Covid-19 pandemic amounted to 104.54 USD is still far from the previous year's per capita income of 218.28 USD. This means that there is a loss of 
income between the Covid-19 and the pre-pandemic of 52.16 percent or about an average of 113.75 USD. Farmers lost more than half their income as in the normal period. The loss of revenue is more due to social restrictions that change the supply-chain pattern of food commodities that farmers produce so that lowering the price is very drastic and difficult to get workers for their agricultural work so that the product results that they produce is less than maximum.

The reduction in the amount of imbalance income with the rate of consumer spending causes farmers to not meet the basic requirements for living or decent living standards (KHL) in South Sumatra. In reality-based on field data about 65.22 percent of total consumption, expenditure is allocated for the expenditure of goods that are not durable. That is, shopping is a nature to meet its basic needs. Consequently, to bridge the gap between revenues and consumption, farmers in South Sumatra during the Covid-19 period fell in a debt trap.

The dramatic survival conditions should be the effort immediately to address the problems faced by farmers in South Sumatra or elsewhere in Indonesia, the same case. Effective measures should be taken by Governments and other institutions, to address them with one of the key components to grant grants direct incentives to the productive efforts of agriculture in South Sumatra and other regions in Indonesia. Attention to the farmer should be given extra because agriculture gives tremendous to the growth of gross domestic income, where agriculture is at least twice as effective in reducing poverty in the growth of gross domestic income compared to non-agricultural fields in Indonesia. Do not let the farmer's condition continuously, because later they will be in the gap of poverty and have a wide impact on various elements of society widely.

The Government must provide financial support to farmers who are urged economically due to the indebtedness of debt during the Covid-19 pandemic. Therefore, the establishment of agro-based industries with the focus of rural areas affected by the Covid-19 pandemic should be given the highest priority, so that the farmer can rise and still try to farm in his village area. Various government programs are made to address the difficult life of these farmers should there be supervision that can be done by the Ministry of Agriculture and Agriculture service continuously from the central level to the area to ensure the facilities and assistance can be well spread to the farmers. However, this policy does not wait for the normal period but should be done from the present and immediately while doing war on the Covid-19 pandemic with the spearhead of farmers as a food producer for Indonesian people widely. Do not arrive at the stage where the farmer is already on wither condition and hard to wake up again.

\section{References}

1. A. Bidarti, D.H. Darwanto, S. Hartono, Jamhari., Agraris, 5, 1, (2019)

2. A. Elaich, Opag, 3, 1 (2018)

3. A. Syuhada, M.E. Armanto, A. Siswanto, M. Yazid, E. Wildayana, Sys. Rev. Pharm., 11, $3(2020)$

4. A.U. Ofuoku, O.I. Ekorhi-Robinson, Opag, 3, 1 (2018)

5. C. Fischer, Opag, 4, 1 (2019)

6. C. Gaanakis, Foods, 9 , (2020)

7. E. Wildayana, Bulg. J. Agr. Sci., 23, 6 (2017)

8. G. Corletto, A. Zezza, R. Banerjee, Glob. Food Secur-Agr, 2, 1 (2013)

9. G. Feenstra, P. Allen, S. Hardesty, J. Ohmart, J. Perez, J. Agr. Food Sys. \& Comm. Dev., 1, 4 (2011)

10. G. Danso-Abbeam, D. Ehiakpor, R. Aidoo, Agr. \& Food Secur., 7, (2018)

11. Irmawati, H. Ehara, R.A. Suwigno, I. Sakagami, Trop. Agr. Dev., 59, 1 (2015) 
12. I. Zahri, D. Andriani, E. Wildayana, Sabaruddin, M.U. Harun, Bulg. J. Agr. Sci., 24, 2 (2018)

13. L. Loko, A. Orobiyi, J. Toffa, S. Fagla, D. Gavoedo, T. Manuele, Opag, 4, 1 (2019)

14. L. Petetin, Eur. J. Risk Regul., 11, 2 (2020)

15. M.K. Bashir, S. Schilizzi, R. Pandit, J. Anim. Plant Sci., 23, 2 (2013)

16. M. Nasrin, S. Bauer, M. Arman, Opag, 3, (2018)

17. N. Apanovich, R.E. Mazur, Agric. \& Food Secur., 7, 87 (2018)

18. R. Siche, Sci. Agropecu., 11, 1 (2020)

19. S. Salam, S. Bauer, Opag, 3, 1 (2018)

20. S.S. Unhale, Q. Bilal, V. Gajghane, S.S. Bharudkar S., P.P. Gadekar, K.R. Biyani, Impact of COVID-19 on food safety and food security, World J. Adv. Health Res., 4, 3 (2020) 